\title{
Integrated Farming System a Promising Farmer and Eco Friendly Approach for Doubling the Farm Income in India - A Review
}

\author{
G. Kiran Reddy ${ }^{*}$, M. Govardhan, Ch. Pragathi Kumari, \\ Md. Latheef Pasha, Md. Ali Baba and B. Rani
}

AICRP on Integrated Farming System, Professor Jayashanker Telangana State Agricultural University, Hyderabad-500030, India

*Corresponding author

\begin{tabular}{|l|}
\hline Ke y w o r d s \\
$\begin{array}{l}\text { Soil health, Long } \\
\text { term experiments, } \\
\text { Organics, Diverse, } \\
\text { Green house } \\
\text { gaseous }\end{array}$ \\
\hline Article Info \\
\hline $\begin{array}{l}\text { Accepted: } \\
22 \text { December } 2019 \\
\text { Available Online: } \\
\text { 20 January } 2020\end{array}$ \\
\hline
\end{tabular}

Keywords

Soil health, Long term experiments, Organics, Diverse, Green house

Accepted:

22 December 2019

20 January 2020

\section{A B S T R A C T}

In India 82 per cent of farmers are small and marginal farmers whose acreage is less than 2 ha. These farmers play a pivotal role in Indian economy. Majority of these farmers practicing mono crop cultivation. Discouraging results of monoculturing (non-integrated system) on crop productivity, led to the development of integrated farming system (IFS) strategy which enables adequate income, employment, nutritional security and eco friendly. IFS has many advantages over the monoculturing. IFS has proven to be the most viable option representing various combinations of agriculture and allied activities viz. cropping system, horticulture, forestry, livestock, poultry, goatery, sericulture, duckery, fishery etc. Different components of the IFS have complementary effects on one other, byproducts or waste of one component will be the food or source of energy for the other component, there by reduces the environmental pollution through recycling of farm waste generated within the farm itself and it reduces the dependence on outside farm inputs (cost effective). Animal and plant waste directly or by composting is added to soil, as the large amount of farm waste will be generated in the IFS because of integration and it helps in improving the soil physical, chemical and biological health. Small and marginal farmers livelihood will be improved and sustained by the adoption of IFS technologies on a large scale all over the India, which enables to double the income of farmers on same piece of land with improved employment and meeting the nutritional requirements of the farm family. 


\section{Introduction}

Thanks to green revolution in India for making the country self sufficient in food grain production (Behere and France, 2016). Today the country has achieved the meritorious heights in food production by extensive cultivation of few crops. At the same time farming turned non profitable for farmers and unsustainable to environment. Subsequent economic liberalization in information technology and industrial sector has generated new employment gateways, resulted in labour shortage for agriculture, forcing the farmers to focus on few less labour demanding enterprises. The per capita income of a person engaged in agriculture is just $1 / 3^{\text {rd }}$ of an average Indian engaged in industrial sector. Uneven distribution, sub divided and scattered farm holdings accounts $45 \%$ of the total cultivable area. This had shown the severe impact on food security of poor farmers and made the farming the hotspot of poverty.

In India, farmers used to maintain diverse enterprises (agriculture, horticulture, dairy, poultry, goatery, duckery, agroforestry, fodder, sericulture, apiculture etc.) since immemorial time for livelihood sustainability. Diverse enterprises complement each other for food, nutritional security, soil health, economic and environmental sustainability. Because of above mentioned reasons and increase in nuclear families, gradually the maintenance of diverse enterprises on farm has lost its viability.

Crop yield maximization by using advanced technology was only the vital point in agriculture in past. Increased single crop productivity caused degradation of soil, environment and society. For survival of mankind apart from food (meat, milk, fruits, oil seeds, honey etc.) requires fibre, fuel, fodder and feed for milk production etc. which balance the environment and farm productivity. Agricultural experts are again promoting the enterprise diversification in farm i.e. retrogress back to immemorial time. In modern day terminology it is called as Integrated Farming System (IFS). IFS helps in elevating the farm family income in short period and it also shows the way to resilience of the farm productivity. With the integration of more number of farm enterprises high farm productivity can be achieved in addition to nutritional security, social, economical and environmental benefits (Mynavathi and Jayanthi, 2015). Family of 5 members requires $110-125 \mathrm{~kg}$ protein, $60 \mathrm{~kg}$ oil and 550 - $575 \mathrm{~kg}$ carbohydrates per annum as recommended by Indian Council of Medical Research. This can be met through IFS approach and success depends on effective planning of the enterprise proportions.

It's difficult for the small and marginal farmers to increase the farm production by investing huge amount of capital for intensive farm activities. In this scenario IFS plays a key role in increasing the farm production with less investment. This can be achieved by optimal utilization of resources, waste recycling and employing the family labour. Waste is utilized as a resource in IFS (Gupta et al., 2012), it eliminates the waste in ecosystem, and in addition increases the farm productivity and reduces the cost of production.

\section{Farm waste recycling or Improved use of resources}

In IFS model crops, horticulture, poultry, dairy, fodder and different components in the system complement each other in terms of utilization of resources generated within the farm. By using different natural resources generated on the field, it reduces the farmers' dependence on market or purchased inputs. 
Kumar et al., (2012) reported that raw animal and bird droppings were recycled into products like FYM, goat manure and vermicompost. This recycled product has nutrient content manifolds higher compared to raw droppings and plant waste. Recycled products have high nutrient content and have lesser volume.

Singh et al., (2012) noticed that $36 \%$ of the total chemical fertilizer can be reduced by recycling of the farm waste that produced within the system. In addition recycling of farm waste improved the soil organic carbon, macro and micronutrient content in soil system.

An IFS experiment conducted at MPKV, Rahuri by Surve et al., (2015), revealed that water use productivity of IFS model (Crop + horticulture + dairy + poultry + fishery) was high at Rs. 991 ha. $\mathrm{cm}$ in comparsion to conventional farming (soyabean+wheat+ fallow) which was Rs. 406 ha. cm. Higher water use productivity in IFS model was because of greater biological activity, efficient utilization of water (because of inclusion of diversified components viz., crop, horticulture, dairy, poultry, fishery)

Kumar et al., (2017) conducted an IFS experiment in main farm, ICAR research complex (Eastern region) for 4 years (2012$15)$ in 0.8 ha area. He concluded that combination of crop + duck + fish + goat has produced good quantity of manure, poultry $2.3 \mathrm{t} / \mathrm{yr}$, duck $1.6 \mathrm{t} / \mathrm{yr}$, goatry $2.9 \mathrm{t} / \mathrm{yr}$, cattle $14.0 \mathrm{t} / \mathrm{yr}$ and plant residue $11.3 \mathrm{t} / \mathrm{yr}$. This generated waste was recycled in the form of FYM, vermicompost, feed etc. Waste recycling has produced $56.5 \mathrm{~kg} \mathrm{~N}, 39.6 \mathrm{~kg} \mathrm{P}$, $42.7 \mathrm{~kg} \mathrm{~K}$ and it was added to the soil system and reduced the cultivation cost by $24 \%$.

Channabasavanna et al., (2009) conducted a study at Tungabhadra project, Karnataka on
IFS in 1 ha area in comparison to conventional system (rice - rice). IFS model comprises of crop (rice, maize, sorghum, vegetables), fishery, poultry and goat. Conventional system (rice - rice) consumed the water about $2370 \mathrm{~mm}$. The proposed IFS model consumed the water $47 \%$ less than conventional system (i.e. $1247 \mathrm{~mm}$ ). Water use efficiency was also high in IFS model $56.8 \mathrm{~kg} / \mathrm{ha} . \mathrm{cm}$ as against $23.7 \mathrm{~kg} / \mathrm{ha} . \mathrm{cm}$ in rice - rice system. Specific energy is the energy required to produce a kilogram of economic yield (units $\mathrm{MJ} / \mathrm{kg}$ ). Specific energy is less for IFS $3.09 \mathrm{MJ} / \mathrm{kg}$ against rice - rice of $5.09 \mathrm{MJ} / \mathrm{kg}$. It indicates the IFS required low input energy to produce a kilogram of produce.

Ansari et al., (2014), reported the findings in the crop + horticulture + piggery + poultry + fishery IFS model in 1 ha. area in north east hill region of India. This model has maximum interlinking of products and resource cycling. From crop components, apart from economic part we get straw, stover etc. which can be used for compost preparation. The compost can be used for the crop production. In similar parallel lines piggery and poultry manure from piggery and poultry farming. Manure can be used for the fishery rearing and for production of crops as organic fertilizer. Waste remaining and excess production of horticultural component is fed to piggery unit. Parts of crop and horticultural waste were fed to fishery. By these interlinkages sustainable crop production and livelihood development is possible.

Channabasavanna and Biradar (2007) conducted a IFS experiment to know the relative performance of rice - fish - poultry system with conventional farming system (rice - rice). They noticed that IFS model generated greater system productivity/day (42.6 kg/ha/day) which was 2.3 times higher over the conventional system (18.2 
$\mathrm{kg} / \mathrm{ha} /$ day). IFS model also recorded greater water use efficiency $(43.2 \mathrm{~kg} / \mathrm{ha} . \mathrm{cm})$ and labour use efficiency $(27.2 \mathrm{~kg} / \mathrm{ha} . \quad \mathrm{cm})$ compared to conventional system who's water use efficiency was $25.1 \mathrm{~kg} / \mathrm{ha}$. $\mathrm{cm}$ and labour use efficiency was $15.3 \mathrm{~kg} / \mathrm{ha} / \mathrm{labour}$. In addition, poultry droppings into the fish pond increased the plankton production (biological activity) and as a result the fish production also increased.

Kumara et al., (2017) conducted a study on IFS at Devangere dist. of Karnataka State under irrigation condition with an area of 1 ha. from 2013-2016. IFS model including crop + horticulture + dairy + sheep generated $41,749 \mathrm{~kg} / \mathrm{l} / \mathrm{no}$ 's of farm waste. The above IFS model requires $300 \mathrm{~kg} / \mathrm{ha}$ inorganic fertilizers and $3000 \mathrm{~kg} / \mathrm{ha}$ organic fertilizers. The nutrient availability from the farm waste was $462.50 \mathrm{~kg}$ from all sources. As the source is organic, the availability of nutrients will be around 25-30 percent in the year, it is estimated that around 35 percent of the nutrient requirement of present IFS model can be met from recycled products that generated within the system. It reduces the investment on chemical fertilizers in addition it enhances the soil health, by increasing organic matter and microbial enzyme activities in the soil.

\section{Improved soil health}

To maintain the sustainable production, there is every need to maintain the soil physical, chemical and biological health. To maintain the soil health, addition of organics to soil is pre requisite. In IFS model, from different components organic wastes are generated and those can be recycled in the system by making vermicompost, compost, direct residue incorporation into soil etc. which helps in increasing the organic carbon and microbial activity of the soil. Organics contain little amounts of essential nutrients, in addition it is source of energy to microorganisms. It is also found to be economical as it saves the investment on chemical fertilizers.

IFS model developed in 1 acre for NE India, includes agriculture + horticulture + fishery + poultry has increased the soil health positively. There was increase in the organic carbon, available $\mathrm{N}$, available $\mathrm{P}$, available $\mathrm{K}$ by $0.06 \%, 4 \mathrm{~kg} / \mathrm{ha}, 1 \mathrm{~kg} / \mathrm{ha}, 4 \mathrm{~kg} / \mathrm{ha}$ respectively after completion of 3 years of IFS practice over initial. This is due to recycling of farm waste i.e. poultry waste, crop stubbles, weeds through vermicomposting and its subsequent application in field thereby increasing soil physical, chemical and biological health of soil in long run (Kumar et al., 2018).

Ponnusamy and Devi (2017), surveyed the 2 districts of Tamil Nadu and 4 districts of Haryana and observed that an adult cow, buffalo, goat, piggery, sheep, poultry produces manure at an average of 10767, 11862, 638, 1460, 635, $11 \mathrm{~kg} /$ year respectively that gives an economic returns of 6460, 5100, 319, 627, 319, 616 Rs/year respectively. Similarly an adult cow, buffalo, goat, piggery, sheep produces urine at an average of 5146, 4453, 255, 547, 317 L/year respectively that gives an economic returns of 3087, 1914, 127, 235, 158 Rs/year respectively. Manure and urine increases the soil health by means of increasing the soil aggregation, soil structure, nutrient availability, microbial growth etc.

Vinodakumar et al., (2017) conducted an IFS field experiment at NE Karnataka from 201214 and noticed that IFS model crop + goat + poultry birds $+\mathrm{HF}$ cow + fishery generated 10 times more crop residues than the crop alone (cotton) cultivation in same piece of land. Similarly IFS model added 19 times more N, 22 times more P, 7 times more K through residues than the crop alone 
cultivation. After two years of experimentation there was more net gain in available $\mathrm{N}$, available $\mathrm{P}$, available $\mathrm{K}(316,41$, $361 \mathrm{~kg} \mathrm{ha}^{-1}$ respectively) than crop alone cultivation $\left(264,37,192 \mathrm{~kg} \mathrm{ha}^{-1}\right.$ respectively).

Crayfish integration with rice farming had high total organic carbon $(20.90 \mathrm{~g} / \mathrm{kg})$, microbial biomass carbon (294.37 mg/kg), dissolved organic carbon $(48.67 \mathrm{mg} / \mathrm{kg}$ ) and particulate organic carbon $(6.24 \mathrm{mg} / \mathrm{kg})$ than the mono culturing of rice total organic carbon $(15.66 \mathrm{~g} / \mathrm{kg})$, microbial biomass carbon $(216.35 \mathrm{mg} / \mathrm{kg})$, dissolved organic carbon $(30.73 \mathrm{mg} / \mathrm{kg})$ and particulate organic carbon $(4.56 \mathrm{mg} / \mathrm{kg})$. This was because of the burrowing habit of crayfish which decrease the bulk density of soil and increases the soil ventilation. So that plough layer will increase in length which increases the root biomass, number and rooting depth as reported by Guohan et al., (2017) in 10 years old long term experiment on rice - crayfish farming system at Bailu lake farm, China.

\section{Pest control}

Expecting higher yields, farmers are applying pesticides in an un-judicious manner in many parts of India, leading to building up of pesticide concentration in the food and food chain system, which is highly dangerous to upcoming generations. But in the IFS model, because of presence of more than 2 diverse enterprises in the field, pesticide consumption can be reduced (Behera et al., 2017).

\section{Employment generation}

Farm labour who depends on agriculture, remain unemployed for $1 / 3^{\text {rd }}$ of the year, because farm activities engage them in cropping season, while they remain un employed during off season. But the IFS model helps in gaining handful of employment, especially to family members due to maintenance of diverse enterprises which are linked to each other, resulting in more labour employment (man days).

Kumar et al., (2012) noticed that integration of crop + fish + duck + goat has produced 752 man days which was followed by crop + fish + cattle (722 man days) which was much more than conventional farming (rice wheat).

Even in the crop component, employment generation was increased due to diversification of crops. Integration of diverse components increased the labour requirement which helped the farmers to get employment year round and had scope for employment to family labour even in lean periods when compared with tradition system.

Sharma et al., (2017) developed 2 IFS models, One 3.5 acre model for rainfed and the other 1.5 acre model for irrigated systems. The models generated employment of 659 and 1033 mandays respectively. The extra employment generated in irrigation system is due to intensive cultivation, animal husbandry activities and diversed nature of enterprises compared with rainfed model. This helps in engaging the family labour more time in field and increases the employment in rural areas.

Govardhan et al., (2018), conducted an IFS experiment in Telangana state, and concluded that IFS model including crop + dairy + sheep + rabbit + hen + quails generated 750 man days of employment whereas rice - maize cropping system, a prevalent cropping system in the state generated 225 man days of employment in 1 ha. area.

Channabasava and Biradar (2007) noticed that integration of crop with animal component (fish and poultry) has generated greater man days (618) over the conventional system (rice-rice) (437). The employment enhancement was around $41.10 \%$ higher in IFS model compared to conventional system. 


\section{Impact on environment}

As the farm waste is utilised for some or other purpose in the IFS system i.e. recycling of farm waste, generation of farm waste is very less or even no waste is generated. This helps in the reducing the green house gases emission from farm and prevents surface and ground water pollution.

Datta et al., (2009) noticed that integration of rice with fish cultivation was found to be economically sound and environmentally secured form the profit to $\mathrm{CO}_{2}$ equivalent emitted under flooded low land condition. Rice integration with fish increased the $\mathrm{CH}_{4}$ emissions and reduced the $\mathrm{N}_{2} \mathrm{O}$ emissions from rice fields in comparison with the rice alone cultivation. The percent increase in $\mathrm{CH}_{4}$ emission was 93 percent and $\mathrm{N}_{2} \mathrm{O}$ emissions decreased by 25.5 percent in rice fish integration compared with the rice alone cultivation. Integration of rice with fish resulted in 4.5 times more net profit than the rice cultivation alone. Nevertheless, integration generated 1.76 times more $\mathrm{CO}_{2}$ equivalents than the rice cultivation alone. When compared with the profit per unit $\mathrm{CO}_{2}$ equivalent emitted, rice integrated with fish has more value than rice cultivation alone.

Rati et al., (2016), conducted a study in two districts of Haryana, India and revealed that integrated farming system was the best approach in reducing the green house gases emission than the reduced tillage, organic farming, improved rice cultivars which emit less methane, adaption of precision farming practices etc.

Xu et al., (2017), conducted an experiment on integration of rice - duck farming in Baimei farm, Nanjing agricultural university and noticed that the total global warming potential (GWP) of integrated rice - duck farming was 13.3 percent less than the conventional rice cultivation. The rice yields were 1.68 percent higher in the integrated rice - duck farming than the conventional farming (rice cultivation). The reasons for the reduction in the GWP in integrated model was due to bioturbation of ducks in the rice fields, with this availability of oxygen to the methanotrophs increased so that methane oxidation increased which reduced the methane emissions from the fields. In rice duck farming, ducks feed on weeds, insects and planktons, reducing the oxygen consumption of weeds, insects and placktons, so that dissolved oxygen and redox potential in the water layer increased (oxidising layer increased). So the methanogenic bacteria became inactive. Other important reason for the reduction in the methanogenic bacteria was the decrease in weeds, insects and placktons, which were fed by ducks. So the food to the methogenic bacteria was reduced.

\section{Farm income}

In India most of the farmers are small and marginal land holders and such small holdings are not economically viable to farmers in the present economic scenario (ASG, 2015).

Vinodakumar et al., (2017) reported that IFS model crop + goat + cow + poultry + fishery gave higher net returns Rs 1,89,069/ha/yr compared to conventional cotton alone $74,552.0 / \mathrm{ha} / \mathrm{yr}$, which was 2.5 times less than the IFS system. This may be due to inclusion of livestock component in the system which generated regular income to farmer.

Mitra et al., (2018) observed that the IFS model fish culture + duck farming + azolla + pulses, given 3 times more income (Rs $1,38,673 / \mathrm{yr}$ ) compared with conventional farming (Rs 45,320/yr) and in a sustainable manner. The benefit cost ratio in IFS model is 2.28 compared to conventional model (1.14). 
Kashyap et al., (2017) noticed that, in the beginning years of IFS, crop component enterprise was most prevalent and gave highest income. As the years progressed, the sizeble contribution of dairy, goatery, horticulture enterprises to income increased. In addition to it value addition has started generating income. As diversification increased, income increased and reduced the dependency on single enterprise.

Mukherjee (2015) reported in mid hill regions of West Bengal, India, farming system involving crop + poultry + dairy + piggery enterprises had positive advantage in terms of economic returns. It has high gross income (Rs. 101482/ha), net returns (Rs. 24935/ha) and sustainability index $(88.5 \%)$ in comparison with crop alone component's (gross income Rs. 57589/ha, net returns Rs. 14002/ha and sustainability index 44.8\%). This is because of good management and no extra attention needed for dairy component in IFS. In IFS model returns per investment was high and very much suitable to mid hill of West Bengal, as most of the soils are marginal.

Ansari et al., (2014) noticed that the income on fish rearing can be increased by good management and healthy maintenance by utilizing same extent of land for fish rearing. In this experiment, common carp and grass carp reared, as common carp survives in the lower layers of water and grass carp survives in the upper and middle layers of water. By using this technology two types of fishes can rear in same extent of area.

Channabasava and Biradar (2007) reported that integration of rice - fish - poultry has given higher net returns (Rs. 48,603/ha./yr) in comparison to conventional farming (rice rice) (Rs. 21,599/ha./yr). The increase was around 2.25 times more in IFS model compared to conventional system.

\section{Biodiversity}

Maintaining the diverse enterprises on the farm is important for maintaining the diversity in the farm, so the ecosystem quality will be enhanced, which provides the ecosystem services effectively (pollination, climatic control, disturbance regulation, pharmacological resources, landscape opportunity).

Soil management via. residue management (in situ) helps in higher microbial activity (beneficial bacteria), more earth worms etc. compared to the inorganically managed fields. In addition it also helps in mineralization, nutrient availability, organic matter decomposition etc. (Das et al., 2015). In IFS model because of presence of diverse enterprises adaptability to agro ecosystem is better. As the adaptability is high they are less prone to pest and diseases, it provides the little bit of resilience to climatic change.

Nayak et al., (2018) conducted long term experiments on rice based Integrated farming system at National Rice Research Insititute, Cuttack and reported that phytoplanktons like diatoms, blue green algae, green algae, euglenophyceae were 1300, 760, 900, 270 avg. no./L of water in rice fish duck integrated farming.

It was $1100,592,890,200$ avg. no. $\mathrm{L}^{-1}$ of water in conventional rice farming. Similarly zooplanktons like cledocera, protozoa, copepod, rotifer were 420, 268, 360, 420 avg. no./L of water in rice fish duck farming. It was 290, 196, 260, 245 avg. no./L of water in conventional rice farming. Microbial population of bacteria, fungi, actinomycetes, bradyrhizobia, denitrifiers, ammonia oxidizers and nitrate oxidisers were greater in number in rice fish duck farming system than the convectional farming system. 
Titi and Ipach (1989) noticed that Lumbricus, earthworms (both in number and biomass), gamasid mites was much higher in integrated system than the conventional system.

In conclusion, decline in the per capita availability of agricultural landholdings day by day gradually reducing the farm income by practicing conventional farming (monocropping or non integrated farming) and it is very difficult to meet the food and other basic requirements of small and marginal farmers in single farm enterprises. As a consequence, large number of farmers is moving away from farming occupation and practicing non-agricultural operations for the survival. The possibility of expanding of cultivable area is meager in India and only way to feed the increasing population is increasing the agricultural output per unit area. So, to meet the basic requirements and to generate the farm income it is essential to integrate the different components of agriculture (i.e. cropping system associated with livestock, apiary, horticulture, sericulture etc.) in a single frame. IFS acknowledge the farm in a holistic approach and consider interactions (among the different components of IFS and components with the environment). IFS is also a unique approach as in this system nothing is wasted, the byproduct or waste of one system becomes the input for the other system.

In a well organised IFS, labour intensive enterprises like dairy, poultry, fruits, vegetables, sericulture, mushrooms etc. can be significantly increase the mandays of employment and income to the farm families in particular to small and marginal farmers, where the surplus of farm labour is available, especially women in the rural India.

IFS helps in conservation of resources by efficient recycling of crop and animal waste that generated within the system in the form of composts helps in reducing the usage of inorganic fertilizers and agrochemicals, thereby minimizing the environmental hazards (residual toxicity hazards of chemicals). In addition expenditure on external inputs will be decreased. So system is economically and ecologically viable. IFS improves the soil fertility by efficient soil use and management which can able to mitigate the GHG emissions. Overall GHG emission per unit of output is very less in IFS. The loss of biodiversity due to monocropping will be considerable retrieved by IFS. Increased biodiversity and enzymatic activities in the IFS encourages the mineralization of nutrients and quick decomposition of organic residues. IFS is a promising strategy for the small and marginal farmers of India to accelerate the farm income and agricultural growth, this transforms the rural farmers life to prosperous.

\section{References}

Ansari M. A., Prakash N., Baishya L. K., Punitha P., Sharma P. K., Yadav J. S., Kabuei G. P., Levis, C. (2014): Integrated Farming System: An ideal approach for developing more economically and environmentally sustainable farming systems for the Eastern Himalayan Region. Indian Journal of Agricultural Sciences, 84 (3): 356-362.

ASG. (2015): Agricultural statistics at a glance 2014. Oxford University Press, New Delhi, India.

Behera U. K., Giri A., Mishra A. K., Bhargavi B., Kar A., Pal G. (2017): Rice-Based Farming Systems and Its Diversification: An Economic Analysis in Coastal Ecologies of Eastern India. Indian Journal of Hill Farming, 30(2): 295-306.

Behera U.K., France J. (2016): Integrated Farming Systems and the Livelihood Security of Small and Marginal Farmers in India and Other Developing Countries. Advances in agronomy, 138: 235-282. 
Channabasavanna A. S., Biradar D. P. (2007): Relative Performance of Different RiceFish-Poultry Integrated Farming System Models with Respect to System Productivity and Economics. Karnataka Journal of Agricultural Sciences, 20(4) : 706-709.

Channabasavanna A. S., Biradar D. P., Prabhudev K. N., Hegde M. (2009): Development of profitable integrated farming system model for small and medium farmers of Tungabhadra project area of Karnataka. Karnataka Journal of Agricultural Sciences, 22(1): 25-27.

Das A., Ramkrushna G. I., Yadav G. S., Layek J., Debnath C., Choudhury B. U., Mohaptara K. P., Ngachan S. V., Das S. (2015): Capturing Traditional Practices of Rice Based Farming Systems and Identifying Interventions for Resource Conservation and Food Security in Tripura, India. Applied Ecology and Environmental Sciences, 3(4): 100-107.

Datta A., Nayak D. R., Sinhababu D. P., Adhya T. K. (2009): Methane and nitrous oxide emissions from an integrated rainfed ricefish farming system of Eastern India. Agriculture, Ecosystems and Environment, 129: 228-237.

Goverdhan M., Latheefpasha Md., Sridevi S., Kumari C. P. (2018). Integrated Farming Approaches for Doubling the Income of Small and Marginal Farmers. International Journal of Current Microbiology and Applied Sciences, 7(3): 3353-3362.

Guohan S., Peng C., Yuan J., Xu X., Zhao S., $\mathrm{Xu}$ D., Wu J. (2017): Changes in soil microbial community composition and organic carbon fractions in an integrated rice-crayfish farming system in subtropical China. Scientfic Reports, 7: 2856-2865.

Gupta V., Rai P. K., Risam K. S. (2012): Integrated Crop-Livestock Farming Systems: A Strategy for Resource Conservation and Environmental Sustainability. Indian Research Journal of Extension Education, 2: 49-54.
Kashyap1 P., Singh M. P., Singh V. K., Prusty A. K., Mishra R. P., Chaudhary V. P. Gangwar B. (2017): Resource integration for livelihood and nutritional security of farmers of Tehri Himalayas of India. Indian Journal of Agricultural Sciences, 87 (9): 1196-1202.

Kumar R., Patra M. K., Thirugnanavel A., Deka B. C., Chatterjee D., Borah T. R., Rajesha G., Talang H. D., Ray S. K., Kumar M., Upadhyay P. K. (2018): Comparative evaluation of different integrated farming system models for small and marginal farmers under the Eastern Himalayas. Indian Journal of Agricultural Sciences, 88(11): 1722-1729.

Kumar S., Shivani., Samal S. K., Dwivedi S. K., Manibhushan. (2017): Enhancement in productivity and income sustainability through integrated farming system approaches for small and marginal farmers of Eastern India. Journal of AgriSearch, 4(2). 85-91.

Kumar S., Singh S. S., Meena M. K., Shivani., Dey, A. (2012): Resource recycling and their management under integrated farming system for lowlands of Bihar. Indian Journal of Agricultural Sciences, 82(6): 504-510.

Kumara O., Sannathimmappa H. G., Basavarajappa D. N., Danaraddi V. S., Pasha A., Rajani S. R. (2017): Integrated Farming System -An Approach towards Livelihood Security, Resource Conservation and Sustainable Production for Small and Marginal Farmers. International Journal of Plant and Soil Science, 15(3): 1-9.

Mitra K., Khan M., Mandal S., Addy R. (2018): Potentiality of integration of different components under fish based farming system for increasing farmers income. International Journal of Agriculture Sciences, 10 (3): 6547-6549.

Mukherjee D. (2013): Potential integrated farming system model in mid hill region of West Bengal situation. Annual Agriculture Research, 34 (3): 264-268.

Mynavathi V.S., Jayanthi C. (2015) Dry land 
integrated farming system - A Review. Agricultural Review,36 (1): 67-72.

Nayaka, P.K., Nayaka, A.K., Pandaa, B.B., Lalb, B., Gautamc,P., Poonama, A., Shahida, M., Tripathia, R., Kumara, U., Mohapatraa, S.D and Jambhulkara, N.N. 2018. Ecological mechanism and diversity in rice based integrated farming system. Ecological Indicators. 91: 359375.

Ponnusamy K., Kousalya M. D. (2017): Impact of integrated farming system approach on doubling farmers' income. Agricultural Economics Research Review, 30: 233240.

Rati M., Seharawat P.S., Anil R., Jasvinder K. (2016): Sequestration of green house gases for eco-friendly agriculture. International Journal of Agriculture Sciences, 8 (26): 1536 - 1539.

Sharma R. L., Abraham S., Bhagat R., Prakash O. (2017): Comparative performance of integrated farming system models in Gariyaband region under rainfed and irrigated conditions. Indian Journal of Agriculture Research, 51 (1): 64-68.

Singh J. P., Gangwar B., Kochewad S. A., Pandey D. K. (2012): Integrated farming system for improving livelihood of small farmers of western plain zone of Uttar Pradesh, India. SAARC Journal of Agriculture, 10(1): 45-53.

Surve U. S., Shinde J. B., Patil E. N. (2015): Performance of integrated farming system model for economic viability, water productivity, employment generation, energy balance and soil health improvement under irrigated condition. International Journal of Tourism Anthropology, 33(2): 1227-1235.

Titi A. E., Ipach U., (1989): Soil Fauna in Sustainable Agriculture: Results of an Integrated Farming System at Lautenbach, F.R.G. Agriculture, Ecosystems and Environment, 27: 561572.

Vinodakumar S. N., Desai B. K., Channabasavanna A. S., Rao S., Patil M. G., Patil S. S. (2017): Resource recycling and their management under integrated farming system for North- East Karnataka. International Journal of Agricultural Sciences, 13(2): 321-326.

Vinodakumar S. N., Desai B. K., Channabasavanna A. S., Rao S., Patil M. G., Patil S. S. (2017): Relative performance of various integrated farming system models with respect to system productivity, economics and employment generation. International Journal of Agricultural Sciences, 13(2): 348-352.

Xu G., Liu X., Wang Q., Yu X., Hang Y. (2017): Integrated rice - duck farming mitigates the global warming potential in rice season. Science of the Total Environment, 575: 58 - 66.

\section{How to cite this article:}

Kiran Reddy, G., M. Govardhan, Ch. Pragathi Kumari, Md. Latheef Pasha, Md. Ali Baba and Rani, B. 2020. Integrated Farming System a Promising Farmer and Eco Friendly Approach for Doubling the Farm Income in India - A Review. Int.J.Curr.Microbiol.App.Sci. 9(01): 22432252. doi: https://doi.org/10.20546/ijcmas.2020.901.254 